ks. Paweł Maciaszek

\title{
Życie i działanie św. Pawła Apostoła w świetle liturgii Kościoła
}

28 czerwca 2008 roku postanowieniem Benedykta XVI rozpoczął się w Kościele Rok św. Pawła. Inspiracją dla papieskiej decyzji była 2000. rocznica urodzin Apostoła Narodów. Na cały ten rok, do 29 czerwca 2009 roku, zaplanowano różne wydarzenia o charakterze historycznym, duszpasterskim, ekumenicznym i kulturalnym, które mają przybliżyć współczesnym uczniom Chrystusa postać Apostoła z Tarsu. W kalendarzu liturgicznym osoba św. Pawła wspominana jest dwukrotnie. Po raz pierwszy w święto jego nawrócenia (25 stycznia), a następnie w uroczystość - wspólną ze św. Piotrem Apostołem - podczas której wierni rozważają jego życie i męczeńską śmierć (29 czerwca). W tym artykule - będącym analizą tekstów liturgicznych o św. Pawle - ukazane zostanie duchowe bogactwo życia tajemnicami zbawienia przekazane w osobie Świętego z Tarsu. Tekst stanowić będzie próbę odpowiedzi na pytanie: jak teksty formularzy mszalnych, czytań biblijnych i liturgii godzin przedstawiają postać, której poznanie zaowocować ma - jak tego pragnie Ojciec Święty - odnowieniem zapału misyjnego wiernych ${ }^{1}$.

W liturgii Kościoła każdy z wiernych może doświadczyć działania Chrystusa, które dokonuje się w objawieniu woli Ojca Niebieskiego i przekazywaniu Wszechmogącemu płynącego od człowieka uwielbienia. Czynności liturgiczne stanowią zatem dla chrześcijanina drogę wyznawania wiary i jej umacniania. W przeżywanym Roku św. Pawła aktualne wydają się zatem pytania: jaki obraz św. Pawła przedstawiają teksty mszy świętej i liturgii godzin o tym apostole? Czy istnieje związek przeżywanego w Kościele czasu poświęconego Świętemu z Tarsu z duchowym życiem człowieka? W jaki sposób wymienione teksty ubogacają ludzkie dusze?

${ }^{1}$ Por. Benedykt XVI, Rok św. Pawła, „L'Osservatore Romano” wyd. pol. 28 (2007) nr 7-8, s. 53. 


\section{Duch Święty przenika światłem wiary}

W liturgiczne święto nawrócenia św. Pawła wierni zgromadzeni na mszy świętej proszą Boga: „niech w tej Ofierze Twój Duch przeniknie nas światłem wiary, którym pobudzał świętego Pawła do głoszenia poganom Twojej chwały"2. Słowa tej modlitwy akcentują fakt, że Apostoł Narodów w swoim życiu i nauczaniu był otwarty na działanie Ducha Świętego, oraz przypominają chrześcijanom o powinności bycia zawsze gotowym na przyjęcie darów Trzeciej Osoby Boskiej. Apostoł, wybrany na głosiciela Dobrej Nowiny, w swoich listach wielokrotnie tłumaczył prawdy wiary dotyczące Tego, który jest Panem i Ożywicielem. Pragnął przez to podkreślić wyjątkowe znaczenie darów Bożych w duchowym życiu człowieka. Św. Paweł jest bowiem kimś, kto - jak podkreślił Benedykt XVI - może o Duchu Świętym nauczyć czegoś ważnego: „Nie ogranicza się on tylko do ukazania dynamicznego i efektywnego oddziaływania Trzeciej Osoby Trójcy Przenajświętszej, ale analizuje również Jej obecność w życiu chrześcijanina, którego tożsamość jest nią naznaczona. Mówiąc inaczej, Paweł podejmuje refleksję nad Duchem, ukazując nie tylko Jego wpływ na postępowanie chrześcijanina, ale także na samo jego życie. On mówi, że Duch Boży w nas mieszka (por. Rz 8, 9; 1 Kor 3, 16) oraz że «Bóg zesłał do serc naszych Ducha Syna swego» (Ga 4, 6). Tak więc, według Pawła, Duch Święty kształtuje nawet najgłębsze pokłady naszej osobowości”3.

Zaakcentowanie w liturgii faktu z życia Apostoła, jakim było pobudzanie go przez Ducha Świętego do głoszenia poganom nauki o Bogu, pokazuje, że jego pneumatologia skupia się wokół działania Trzeciej Osoby Boskiej w człowieku i we wspólnocie Kościoła ${ }^{4}$. W postaci Świętego można dostrzec, jak Pan i Ożywiciel przenika światłem wiary serce człowieka oraz pobudza go do głoszenia chwały Boga. W swoich listach Paweł wspomina takie doświadczenie, które pozwalało mu na apostolską działalność. Czuje się on podtrzymywany przez Ducha w czasie pokonywania trudności (por. 1 Tes 1, 5). Ci, na których spoczywa Duch Boży - jak przypomina biblijny tekst przeznaczony do modlitwy porannej w dniu 29 czerwca - mogą cieszyć się nawet wówczas, kiedy z powodu Chrystusa są prześladowani: „Cieszcie się, im bardziej jesteście uczestnikami cierpień Chrystusowych (...) albowiem Duch chwały, Boży Duch na was spoczywa” (1 P 4, 13-14)5.

${ }^{2}$ Modlitwa nad darami, [w:] Mszat rzymski dla diecezji polskich, Poznań 1986, s. 9.

${ }^{3}$ Benedykt XVI, Pawet - Duch Święty w naszych sercach, „L'Osservatore Romano” wyd. pol. 28 (2007) nr 3, s. 32.

${ }^{4}$ Por. J. Stępień, Teologia świętego Pawła. Człowiek i Kościół w zbawczym planie Boga, Warszawa 1979, s. 382-383.

${ }_{5}^{5}$ Jutrznia, [w:] Liturgia Godzin. Codzienna modlitwa ludu Bożego, t. 3, Poznań 1987, s. 1281. 
Apostoł otwarty na dary Trzeciej Osoby Boskiej - przypominał Jan Chryzostom - podejmując trud przekazywania Dobrej Nowiny, „bardziej pragnął obelg i wynikających z głoszenia Ewangelii upokorzeń niż my zaszczytów".

Święty Paweł ukazuje Osobę Ducha Świętego jako Tego, który czyni ludzi synami Bożymi i dzięki któremu - jak napisał w jednym ze swoich listów - chrześcijanie mogą wołać „Abba, Ojcze” (Rz 8, 15). Dzięki Jego łasce, otrzymanej na chrzcie, dopełnia się w człowieku zbawcze dzieło Chrystusa. Apostoł szczegółowo analizuje ludzkie życie według ciała i ducha. Zapisał on pewnego rodzaju katalog cnót, którymi charakteryzuje się chrześcijanin posiadający owoce Ducha (por. Ga 5, 22; Rz 6, 19-22; Ef 5, 9) ${ }^{7}$. Nową godność człowieka, którą nadaje Trzecia Osoba Boska, scharakteryzował w swoim nauczaniu Benedykt XVI, przypominając, że „chrześcijanin, jeszcze zanim zacznie działać, posiada już bogate i owocne życie wewnętrzne, dane mu w sakramentach chrztu i bierzmowania. To życie wewnętrzne stawia go w obiektywnej i pierwotnej relacji synostwa w odniesieniu do Boga. Oto nasza wielka godność: godność wynikająca stąd, że nie jesteśmy tylko obrazem Boga, ale synami Bożymi. Jest to także wezwanie, abyśmy przeżywali nasze synostwo, abyśmy coraz lepiej uświadamiali sobie, że jesteśmy przybranymi synami w wielkiej rodzinie Bożej. Jest to zachęta, by przemienić ten obiektywny dar w subiektywną rzeczywistość, kształtującą nasz sposób myślenia, działania, życia. Bóg uznaje nas za swoich synów, wyniósł nas do podobnej, choć nie równej godności, jaką ma sam Jezus, jedyny prawdziwy Syn w pełnym znaczeniu. W Nim zostaje nam dana lub przywrócona synowska kondycja oraz ufność i wolność w relacji z Ojcem"».

W nauczaniu św. Pawła - kiedy ukazuje on działanie Trzeciej Osoby Boskiej - nie można pominąć udzielanego daru wolności, który staje się udziałem wszystkich pozwalających się prowadzić pełnemu mocy Duchowi Świętemu. Na tę tajemnicę zbawienia uwagę wiernych zwrócił ten, który ogłosił Rok św. Pawła: „Jeżeli, jak zauważyliśmy, dla Łukasza Sobór Jerozolimski wyraża działanie Ducha Świętego, dla Pawła stanowi decydujące uznanie wolności, dzielonej przez wszystkich, którzy w nim uczestniczyli: wolności od zobowiązań wypływających z obrzezania i z Prawa; tej wolności, do której «wyswobodził nas Chrystus, byśmy byli wolni» i nie pozwolili sobie więcej nałożyć jarzma niewoli (por. Ga 5, 1). Dwa sposoby, w jakie Paweł i Łukasz opisują zgromadzenie w Jerozolimie, łączy wyzwalające S. 1068.

${ }^{6}$ Św. Jan Chryzostom, Homilia 2 ku czci św. Pawła, [w:] Liturgia Godzin..., dz. cyt., t. 3,

${ }^{7}$ Por. R. Penna, Św. Pawet z Tarsu, tł. B. A. Gancarz, Kraków 2008, s. 87-88.

${ }^{8}$ Pawet - Duch Święty w naszych sercach, dz. cyt., s. 32. 
działanie Ducha, albowiem «gdzie jest Duch Pański - tam wolność», jak powie w Drugim Liście do Koryntian (por. 3, 17). Wszelako, jak ukazuje się to bardzo wyraźnie w Listach św. Pawła, wolność chrześcijańska nie utożsamia się nigdy z rozwiązłością czy z samowolą; wypełnia się ona w zgodności z Chrystusem i tym samym w prawdziwej służbie braciom, przede wszystkim najbardziej potrzebującym".

Kolejną perspektywą refleksji Apostoła Narodów o Duchu Świętym jest wspólnota Kościoła. Napotkane w Koryncie problemy ludu Bożego przyczyniły się do tego, że św. Paweł dokonał systematycznego ujęcia sposobów działania Trzeciej Osoby Trójcy Przenajświętszej we wspólnocie wiernych. Sytuacja w gminie wymagała podania jasnych kryteriów odróżnienia działania Ducha Bożego od działania złego. „Podane w 1 Kor 12, 2n kryterium oceny charyzmatów zaskakuje prostotą. Zwykłe wyznanie Jezusa jako Pana, zdaniem Apostoła, można uczynić tylko w mocy Ducha, i na odwrót, przeklinanie Jezusa stanowi pewny dowód braku Ducha"10.

Teksty liturgiczne, ukazujące postać Apostoła z Tarsu, potwierdzają prawdę o działaniu Boga w człowieku wolnym, otwartym na Jego łaskę. Niezwykłość św. Pawła polega na tym, że zanim głosił Chrystusa z bezgranicznym oddaniem, najpierw duchowo przylgnął do Niego i zawsze przeżywał Jego obecność w swej duszy. Sukcesy apostolskie nie były zatem wynikiem obmyślonej taktyki czy starannie dobranych zamiarów, lecz stanowiły owoc niezachwianej wiary i osobistego doświadczenia Zbawiciela oraz dawania o Nim bezwzględnego świadectwa. Znając wyjątkową rolę Boga Ożywiciela w duchowym życiu człowieka, Paweł zapewnia: „Nikt nie może powiedzieć bez pomocy Ducha Świętego: «Panem jest Jezus»" (1 Kor 12,3). Poznanie tajemnicy wiary i życie nią na co dzień - jak widać na przykładzie Apostoła z Tarsu - jest możliwe tylko w Duchu Świętym ${ }^{11}$.

Przybliżając swoim braciom w wierze postać Pana i Ożywiciela, Swięty z Tarsu wskazuje na charyzmaty, jakimi Bóg obdarza, aby Jego lud mógł żyć i rozwijać się. Dary te - mądrość słowa, uzdrawianie, umiejętność poznawania, proroctwo, rozpoznawanie duchów, dar języków i ich tłumaczenia - mają służyć dobru gminy i zbudowaniu całego Kościoła powszechnego, a nie osobistemu dobru charyzmatyków. Z tej perspektywy wydaje się zrozumiałe, że dla Apostoła Narodów właśnie Duch Święty odgrywa decydującą rolę w tworzeniu Kościoła. „Wszyscyśmy bowiem w jednym Duchu

\footnotetext{
${ }^{9}$ Benedykt XVI, Spór w dobrej sprawie (katecheza z 1 X 2008).

${ }^{10}$ J. Gnilka, Teologia Nowego Testamentu, tł. W. Szymona, Kraków 2002, s. 127-128.

${ }^{11}$ Por. Katechizm Kościoła Katolickiego, 683.
} 
zostaliśmy ochrzczeni, [aby stanowić] jedno Ciało" $\left(1\right.$ Kor 12, 13) ${ }^{12}$. Bóg jak obwieszcza biblijny tekst modlitwy brewiarzowej w dniu św. Pawła - nie czyni różnicy między ludźmi, pragnąc każdemu udzielać Ducha Świętego dla osiągnięcia świętości na drodze wzrostu w wierze: „Bóg wybrał mnie, aby z moich ust poganie usłyszeli słowa Ewangelii i uwierzyli. Bóg, który zna ich serca, zaświadczył na ich korzyść, dając im Ducha Świętego tak samo jak nam. Nie zrobił żadnej różnicy między nami a nimi, oczyszczając przez wiarę ich serca" (Dz 15, 7b-9) ${ }^{13}$.

Pragnieniem Apostoła Narodów, któremu objawiony został odwieczny zamysł Ojca Niebieskiego odnośnie do wspólnoty ludu Bożego, która w Chrystusie i z Chrystusem - stanowi istotny element powszechnej i pełnej miłości ekonomii zbawienia, było „wydobyć na światło, czym jest wykonanie tajemniczego planu" (Ef 3, 9). Wierni, modlący się tekstami liturgii, uwielbiają miłosiernego Boga i składają Mu dziękczynienie przez i za Kościół. Modlitwa ta uświadamia chrześcijaninowi jego wybranie i powołanie do bycia przybranym dzieckiem Bożym. Ponadto w tym liturgicznym dialogu wierni wspierani są wstawiennictwem Apostoła z Tarsu i powołują się na to, czego Bóg przez niego dokonał. Prawdy te wyraźnie zaakcentowane zostały chociażby w takich modlitwach, jak:

„Pawle Apostole (...)

Z Tobą się korzymy przed Ojca mądrością

I z Tobą wielbimy Syna, grzesznych Zbawcę,

Przyzywamy Ducha, by wszystkich zjednoczył

W Kościele Chrystusa jako Jego członki”"14,

„Chwała Tobie, Panie, za Twój święty,

zbudowany na fundamencie Apostołów Kościół,

bo w nim stajemy się członkami jednego Ciała"15.

„Zaprawdę godne to i sprawiedliwe, a dla nas zbawienne, abyśmy Tobie składali dziękczynienie i Ciebie wychwalali, Panie (...) Ty nam pozwalasz z radością oddawać cześć świętym apostołom Piotrowi i Pawłowi. (...) Paweł otrzymał łaskę jasnego rozumienia prawd wiary i stał się nauczycielem narodów pogańskich. Obdarzeni różnymi darami zgromadzili w jednym Kościele wyznawców Chrystusa"16.

${ }^{12}$ Por. Benedykt XVI, Pawet - życie w Kościele, „L'Osservatore Romano” wyd. pol. 28 (2007) nr 3, s. 33-34; Y. Congar, Wierzę w Ducha Świętego. Duch Święty w „ekonomii”, Objawienie i doświadczenie Ducha, t. 1, tł. A. Paygert, Warszawa 1995, s. 72.

${ }^{13}$ Modlitwa w ciagu dnia, [w:] Liturgia Godzin..., dz. cyt., t. 3, s. 1283.

${ }^{14}$ Jutrznia. Hymn, [w:] Liturgia Godzin ..., dz. cyt., t. 3, s. 1069.

${ }^{15}$ Jutrznia. Prośby, [w:] Liturgia Godzin ..., dz. cyt., t. 3, s. 1070.

${ }^{16}$ Prefacja o świętych Apostołach Piotrze i Pawle. Dwojakie posłannictwo świętych Piotra i Pawła w Kościele, [w:] Mszał rzymski dla diecezji polskich, dz. cyt., s. 83*. 


\section{Głoszenie Dobrej Nowiny wszystkim narodom}

W modlitwach Kościoła przeznaczonych na dni św. Pawła podkreślany jest fakt powołania Apostoła do głoszenia Dobrej Nowiny. Wystarczy wymienić choćby jedną z modlitw mszalnych: „obchodzimy dzisiaj nawrócenie świętego Pawła Apostoła, którego powołałeś do głoszenia Dobrej Nowiny wszystkim narodom"17 oraz Prośby w wieczornej modlitwie ludu Bożego: „Ty (Chryste) posłałeś Pawła Apostola, aby głosił Ewangelię poganom, spraw, aby wszyscy ludzie usłyszeli słowo zbawienia" ${ }^{18}$. Kiedy dokonuje się analizy dzieła przekazywania zbawienia, warto zaznaczyć, że ten najstarszy teolog Nowego Testamentu inaczej niż inni Apostołowie zetknął się z Dobrą Nowiną. Wychowany w tradycji judaizmu i hellenizmu, do poznania Ewangelii doszedł dzięki bezpośredniemu objawieniu ${ }^{19}$. Sam wyraźnie stwierdził: „nie otrzymałem jej bowiem ani nie nauczyłem się od jakiegoś człowieka, lecz objawił mi ją Jezus Chrystus" (Ga 1, 12).

Poznanie Ewangelii przez św. Pawła dokonało się w taki sposób, że stanowiło jednocześnie wezwanie do głoszenia jej innym. Dlatego też egzegeci często akcentują kerygmatyczny, czyli przepowiadający podstawowe prawdy wiary, charakter jego tekstów ${ }^{20}$. To przekazywanie Ewangelii jest dla niego udziałem w procesie zbawczym i dlatego napisał, że jest ona „mocą Bożą ku zbawieniu dla każdego wierzącego” (Rz 1, 16). Jej treści rozumie zarówno jako prawdę o odkupieniu dokonanym przez Chrystusa, jak i jako orędzie skierowane do każdego człowieka. Rozumie, że te treści są tak istotne, że przypomina ich znaczenie tym, którzy je słyszeli: „W Nim [Chrystusie] także i wy, usłyszawszy słowo prawdy, Dobrą Nowinę o waszym zbawieniu, (...) zostaliście naznaczeni pieczęcią, Duchem Świętym, który był obiecany" (Ef 1, 13).

Pochodzący z Tarsu nauczyciel wiary pragnie wszystkich przekonać o darmowości i powszechności zbawienia, którego dokonał Zbawiciel. Nowość teologii św. Pawła polega na tym, że śmierć i zmartwychwstanie Jezusa zawsze widzi on w perspektywie człowieka i jego zbawienia, co znalazło odbicie przy wyjaśnianiu tych formuł wiary, z których ludzie mogą dowiedzieć się, że Chrystus umarł „za nas” i „za nasze grzechy” (Rz 5, 8; 1 Kor 15,3). Apostoł, poznając dzieło zbawienia i doceniając jego niezwykłą wartość dla życia, był głęboko przekonany, że nie wolno mu zajmować się

\footnotetext{
${ }^{17}$ Kolekta, [w:] Mszat rzymski dla diecezji polskich, dz. cyt., s. 9'.

${ }^{18}$ I Nieszpory, [w:] Liturgia Godzin..., dz. cyt., t. 3, s. 1275; II Nieszpory, [w:] Liturgia Godzin..., dz. cyt., t. 3, s. 1286.

${ }^{19}$ Por. J. Gnilka, Teologia Nowego Testamentu, dz. cyt., s. 32.

${ }^{20}$ Por. H. Langkammer, Teologia Nowego Testamentu. Pawet. List do Hebrajczyków, t. 2, Wrocław 1984, s. 16-17.
} 
żadną inną działalnością, tylko głoszeniem Dobrej Nowiny. Nieustannie towarzyszyła mu świadomość wybrania go do realizacji Bożego planu zbawienia. Przemawiając do tych, do których był posłany, zaświadczał: „Biada mi bowiem, gdybym nie głosił Ewangelii!” $\left(1\right.$ Kor 9, 16) ${ }^{21}$.

Imperatyw głoszenia Ewangelii wynikał z troski Apostoła o zbawienie wszystkich ludzi. Zatroskany o nich pytał, jakby w ich imieniu: „Jakże mieli uwierzyć w Tego, którego nie słyszeli? Jakże mieli usłyszeć, gdy im nikt nie głosił?” (Rz 10,14) ${ }^{22}$. Stąd też jego życie i teologia pozwalają zgromadzonemu na liturgii ludowi Bożemu odnaleźć odpowiedź na pytanie, czy głoszenie Dobrej Nowiny wszystkim, również niewierzącym, to także zadanie współczesnego Kościoła.

O aktualności tego pytania i pilnej potrzebie znalezienia na nie odpowiedzi przypomniał w swoim nauczaniu Benedykt XVI, który podkreślił całkowite zaangażowanie się św. Pawła w głoszenie Dobrej Nowiny. Temu dziełu Apostoł oddał się bez względu na trudności i cierpienia. Dla chrześcijan, którzy w liturgii przypominają sobie jego postawę, jest to-zdaniem papieża - wezwanie do przyjęcia Ewangelii. Jest to wezwanie do ożywienia pragnienia, aby serca wiernych zostały poruszone słowem Pańskim i aby każdy z nich mógł przekazywać współczesnemu światu prawdę Chrystusową (por. 2 Kor 11, 21-28; 1 Kor 9, 23) 23 .

Apostoł zaświadcza, że jedynie Chrystus - którego wyróżnia sprawiedliwość - jest tym, który wyzwala z niewoli grzechu. Dochowując wierności danym obietnicom, Bóg usprawiedliwia w swoim Jednorodzonym Synu; uświęca ludzi i czyni ich przedmiotem swojej miłości. Tłumacząc istotę Ewangelii, św. Paweł kilkakrotnie zatrzymuje się na zagadnieniu „usprawiedliwienia" i wyjaśnia je jako darmową, niczym niezasłużoną przez człowieka dobroć Boga (Rz 3, 21-26. 29). Po czasie, w którym dokonało się odkupienie rodzaju ludzkiego, Ojciec niebieski może zaspokoić obecne w człowieku pragnienie zbawienia. Jedynym warunkiem - jaki może spełnić każdy z ludzi - jest kroczenie drogą wiary, na której oddaje się on w ręce Boga ofiarującego w Chrystusie przebaczenie i pojednanie ${ }^{24}$.

Warto w tym miejscu zauważyć, że teksty liturgiczne o św. Pawle, w których wielokrotnie wspominane jest jego dzieło głoszenia Dobrej Nowiny,

${ }^{21}$ Por. E. P. Sanders, Paul, Oxford 1991, s. 2.

${ }^{22}$ Por. K. Romaniuk, Święty Pawet-życie i dzieło, Katowice 1995, s. 195; J. Gnilka, Teologia Nowego Testamentu, dz. cyt., s. 93.

${ }^{23}$ Por. Benedykt XVI, Paweł wzorem głoszenia Ewangelii dzisiejszemu światu (katecheza z 27 VII 2008).

${ }^{24}$ Por. S. Cipriani, Duchowe nauczanie świętego Pawła Apostoła, tł. W. Linke, K. Kubis, Kraków 2007, s. 94-95. 
przypominają, iż słowo „ewangelia” ma u Apostoła z Tarsu znaczenie bardziej podstawowe. Używa go - jak tłumaczy ks. Tomasz Jaklewicz w formie czasownikowej, na oznaczenie czynności obwieszczania zbawienia oraz częściej w formie rzeczownikowej, aby określić treść głoszonej prawdy. Teksty celebracji mszy świętej, liturgii godzin i nabożeństw przywołują listy Apostoła, w których pisze on o Ewangelii Bożej, jedynej Ewangelii Chrystusa (por. Rz 1, 1; Ga 1, 6-9) oraz o Ewangelii, którą głosi i którą nazywa naszą (por. 1 Tes 1,5) 25 $^{25}$ W ten sposób Apostoł uczy wszystkich odczytywania słowa Bożego jako wezwania i zaproszenia do przekazywania jego treści dalej. Ilekroć słowa modlitwy liturgicznej kreślą przed wiernymi postać niestrudzonego głosiciela Dobrej Nowiny wszystkim narodom, uświadamiać powinny charakter, jakim odznacza się Ewangelia: „Jest to objawienie, które w pełni zostanie odkryte dopiero przy końcu czasów. Ewangelia ma charakter dynamiczny - jest «mocą Bożą ku zbawieniu każdego wierzącego» $(\mathrm{Rz} 1,16)$. Jest obietnicą. Ma charakter normatywny - w jej świetle trzeba czytać Stary Testament i wszystko. Jej głoszenie jest misją skierowaną do wszystkich ludzi. Paweł uważał, że istnieje tylko jedna Ewangelia, czyli prawda o Jezusie Chrystusie, której był niegodnym sługą"26.

Dla Apostoła Narodów istotą Ewangelii nie jest samo nauczanie Jezusa, ale tajemnica Jego śmierci i zmartwychwstania, która przynosi każdemu człowiekowi przebaczenie grzechów, wolność, nadzieję, otwiera mu drogę do nieba. Święty z Tarsu rozumie Ewangelię jako zwiastowanie zbawienia dokonanego przez Zbawiciela. On nie pojmuje jej jedynie jako sposób przekazywania faktów czy informacji, ale jako kontynuację działania Bożego. Zbawienie dokonane przez Chrystusa staje się dostępne dla człowieka w głoszonym słowie. Św. Paweł, który sam doświadczył wyzwalającej mocy Ewangelii, pragnie uświadomić ludziom, że ma ona taką moc i wymaga od człowieka wiary oraz nawrócenia. On - jak charakteryzuje Apostoła francuski jezuita Jacques Guillet - jest świadkiem entuzjazmu, jaki rodzi się w człowieku na początku poznania Chrystusowego orędzia zbawienia. Następnie droga przekazywania Ewangelii wiedzie przez samotność i mękę. Paweł - choć podążający z Dobrą Nowiną do obcych i pozostający na łasce tych, którzy znali go jako prześladowcę - wierzy w ostateczne zwycięstwo dobra. Nie przeszkadza mu w tym fakt, że wyraźnie dostrzega w świecie zło i na co dzień go doświadcza ${ }^{27}$.

${ }^{25}$ Por. Modlitwy na Rok świętego Pawła Apostoła, red. K. Bełkot, Częstochowa 2008. W zbiorze znajdują się m.in. trzy formularze mszy świętej oraz trzy obrzędy nabożeństw o św. Pawle Apostole.

${ }^{26}$ T. Jaklewicz, Ewangelia Pawła, „Gość Niedzielny” 85 (2008) nr 42, s. 29.

${ }^{27}$ Por. J. Guillet, Święty Pawet. Apostoł Narodów, tł. P. Rak, Kraków 2003, s. 128. 


\section{Ofiarowanie życia drogą miłowania Chrystusa i braci}

Antyfona rozpoczynająca mszę świętą w uroczystość świętych Apostołów Piotra i Pawła przypomina ich jako tych, „którzy własną krwią użyźnili Kościół, pili kielich Pański i stali się przyjaciółmi Boga"28. Męczeństwo, wyjątkowy rys biografii Apostoła z Tarsu, wskazuje na powołanie człowieka do wierności Chrystusowi także w cierpieniu i śmierci. Słuchając w liturgii o licznych podróżach św. Pawła, o podejmowanych przez niego wyzwaniach i znoszonych upokorzeniach, wierni mogą uświadomić sobie cenę wierności Chrystusowi. O swojej służbie Temu, którego poznał pod Damaszkiem, autor 1 Listu do Koryntian pisał: „Aż do tej chwili łakniemy i cierpimy pragnienie, brak nam odzieży, jesteśmy policzkowani i skazani na tułaczkę, i utrudzeni pracą rąk własnych" (4, 11-12). W swoim nauczaniu wyraźnie zaakcentował nieustanne trwanie przy Chrystusie, a przedstawiając się i określając swoją postawę, nazywa siebie Jego sługą i niewolnikiem (por. Ga 1, 10; Rz 1, 1). Chrześcijanie powinni się zatem całkowicie oddać Panu, ponieważ przynależność do Niego jest całkowita i definitywna, nawet śmierć nie może jej zmienić: ,jeżeli bowiem żyjemy, żyjemy dla Pana; jeżeli zaś umieramy, umieramy dla Pana. I w życiu, więc i w śmierci należymy do Pana" (Rz 14, 8) ${ }^{29}$.

Wolność św. Pawła wobec śmierci pomaga zrozumieć często używane przez niego wyrażenie „w Chrystusie” (por. Rz 15, 17; Ga 2, 20; 1 Kor 1, 4; 2 Kor 5, 17; Flp 1, 13). Być może był to efekt osobistego spotkania Zbawiciela, ale zapewne pisząc w taki sposób, wyraża zażyłą przyjaźń ze swoim Panem. Chrystus jest tak bardzo obecny w życiu Apostoła, że śmierć traktuje on jako nagrodę: „Dla mnie bowiem żyć - to Chrystus, a umrzeć - to zysk" (Flp 1, 21). Na śmierć patrzy jako na szansę spełnienia się jego pragnienia, aby opuścić ciało i stanąć w obliczu Pana (por. 2 Kor 5, 8). O jeszcze pełniejszym zjednoczeniu z Nim przez śmierć mówi wtedy, kiedy dla dobra wykonywanej pracy apostolskiej zgadza się pozostać przy życiu ${ }^{30}$. Dla św. Pawła w rozstaniu z doczesnością nie ma niczego z tragizmu, wręcz przeciwnie, pojmuje je jako możliwość zjednoczenia z Chrystusem nie przez wiarę, ale przez bezpośrednie uczestnictwo w Jego chwale ${ }^{31}$.

Przypomniana w liturgii, wyrażająca się w ofiarowaniu życia Bogu droga do przyjaźni z Chrystusem tłumaczy „fakt, że Kościół narodzony z krzyża Chrystusa również dzisiaj zaznaje prześladowań i męczeństwa, staje się wy-

\footnotetext{
${ }^{28}$ Msza w dzień. Antyfona na wejście, [w:] Mszał rzymski dla diecezji polskich, dz. cyt., s. 101'. ${ }^{29}$ Por. E. Szymanek, Wykład Pisma Świętego Nowego Testamentu, Poznań 1990, s. 270.

${ }^{30}$ Por. A. Jankowski, Listy więzienne, Poznań 1962, s. 96.

${ }^{31}$ Por. J. Stępień, Teologia świętego Pawła ..., dz. cyt., s. 230.
} 
razistym znakiem nadziei dla misji. Czyż moglibyśmy nie wspomnieć w tym kontekście, że misjonarze i zwykli wierni nadal oddają życie dla imienia Jezusa? Także historia ostatnich lat dowodzi, że prześladowanie staje się zasiewem nowych chrześcijan oraz że cierpienie, znoszone dla Chrystusa i Ewangelii, jest nieodzownym warunkiem wzrostu Królestwa Bożego"32. Św. Paweł, który spotkał Chrystusa uwielbionego i zmartwychwstałego, całkowicie utożsamiał się z Jezusem umęczonym i ukrzyżowanym (por. Rz 6, 3-4; 2 Kor 1, 5). Postawa taka jest przykładem trwania w zjednoczeniu z Nim bez względu na przeżywanie różnych codziennych wydarzeń.

Teksty w oficjum brewiarzowym z 25 stycznia podkreślają, że Chrystus stanowił życie Apostoła Narodów, a pokładana w obietnicy zbawienia ufność pozwoliła Świętemu z Tarsu przybić się do krzyża i w śmierci zobaczyć zysk ${ }^{33}$. W tym dniu wierni - czytając w brewiarzu homilię złotoustego doktora Kościoła - poznają to, co łączyło św. Pawła z Jezusem: „Cieszył się miłością Chrystusa, darem najwyższym. Mając ją, uważał się za najszczęśliwszego z ludzi. (...) Jedno tylko było dla niego najwyższą katuszą, stracić ową miłość. (...) Mieć ją, oznaczało życie, świat cały, szczęście aniołów, dobra obecne i przyszłe, królestwo, wszelkie obietnice i w ogóle niekończące się dobro. (...) Za dziecinne igraszki uważał śmierć, kary i tysięczne cierpienia, byleby tylko mógł cierpieć dla Chrystusa" ${ }^{34}$.

Obdarowany wyjątkową bliskością ze Zbawicielem, Apostoł poznaje jej naturę i docenia jej niezwykłą wartość, które ukazuje w hymnie na cześć miłości (por. 1 Kor 13). Jest jednocześnie przekonany, że owo zjednoczenie z Chrystusem jest owocem udziału w Jego męce. Przez cierpienie, które człowiek przeżywa w łączności ze swoim Panem, zacieśniają się więzy ludzkiej przyjaźni z Bogiem (por. 2 Kor 1,5). Chrystus staje się jednym z tymi, którzy razem z Nim cierpią. „Pierwsze wspólnoty chrześcijańskie, do których zwraca się Paweł, wiedzą doskonale, że Jezus już zmartwychwstał i żyje; Apostoł chce przypomnieć nie tylko Koryntianom czy Galatom, ale nam wszystkim, że Zmartwychwstały jest zawsze Tym, który został ukrzyżowany. «Zgorszenie» i «głupstwo» krzyża polegają właśnie na fakcie, że tam, gdzie zdaje się być wyłącznie niepowodzenie, cierpienie, porażka, tam właśnie jest cała moc bezgranicznej Miłości Boga, ponieważ krzyż jest wyrazem miłości, a miłość jest prawdziwą mocą, która objawia się właśnie w tej pozornej słabości”35.

32 Jan Paweł II, Wielkie znaki obecności Ducha Świętego. Orędzie na Światowy Dzień Misyjny 1998, $\mathrm{nr} 4$.

${ }^{33}$ Por. Jutrznia. Hymn, [w:] Liturgia Godzin ..., dz. cyt., t. 3, s. 1069; B. Nadolski, Święty Pawet. Wielki Apostot, Kraków 2008, s. 27-28.

${ }^{34}$ Św. Jan Chryzostom, Homilia 2 ku czci św. Pawła, dz. cyt., s. 1067.

${ }^{35}$ Benedykt XVI, Krzyż centrum historii ludzkości (katecheza z 29 X 2008). 
Apostoł odznaczał się wyjątkową odwagą, kiedy w swoim nauczaniu podążał drogą sprzeczną z myśleniem Żydów (dla których krzyż jest zgorszeniem) i Greków (dla których kryterium osądu, by oprzeć się krzyżowi, jest rozum). Opierając swoje przepowiadanie na słowie zakotwiczonym w tajemnicy krzyża, nade wszystko chciał ukazać moc Boga i objawić Jego miłość, które są całkowicie różne od ludzkich. Greka urzekał swoim pięknem świat uczyniony przez Boga, Żyd natomiast zachwycał się dokonywanymi poprzez wieki zbawczymi dziełami Wszechmogącego, św. Paweł zaś otrzymał odpowiedź na pytanie o najpiękniejsze dla chrześcijanina dzieło, jakim jest śmierć na krzyżu. Ten znak zbawienia Apostoł umieszcza w centrum życia Kościoła i przez to ukazuje się jako wzór do naśladowania. Nikt bowiem nie jest mocniejszy i nie kocha bardziej niż ten, kto życie swoje oddaje dla bliźnich (por. J 15, 13) ${ }^{36}$.

Chrystusowa miłość, jaką cieszył się Apostoł z Tarsu, pozwoliła mu - jak przypomina modlitwa mszalna w święto jego nawrócenia - „troszczyć się o wszystkie Kościoły" ${ }^{37}$. W jego listach znajduje się wiele fragmentów, które bezpośrednio wskazują na miłość jako najważniejszy motyw apostolskiej działalności, rozumiany jako dar otrzymany od Boga i jako najbardziej dojrzała odpowiedź człowieka (por. 1 Kor 13, 1-13; 2 Kor 5, 12-18; Ga 6, 14n; Rz 5, 5; 8, 35n). Wszystko, co składa się na codzienność Pawła, i każda jego postawa względem braci wynika z twierdzenia: „Albowiem miłość Chrystusa przynagla nas” (2 Kor 5, 14). Z tego przynaglenia zrodziła się pewność, że moc Bożej łaski skierowana jest do wszystkich ludzi i nie omija nawet tych, którzy nie trwają w przyjaźni ze Zbawicielem. Apostoł pogan jest dla ludzi przykładem, który pociąga ich do miłości Chrystusa i pozwala odnaleźć w Nim źródło chrześcijańskich postaw.

Dla Apostoła Narodów miłość stanowi najważniejszą normę chrześcijańskiego życia. Świadczy o tym fakt, że kiedy zetknął się z problemami wspólnoty chrześcijan w Koryncie, pisze do nich list zawierający Hymn o miłości (1 Kor, 13, 1-13). Fragment ten stanowi kulminację jego nauki o charyzmatach i zawiera najważniejsze wymaganie stawiane uczniom Chrystusa. Miłość jest niezbędna w życiu chrześcijanina, stanowi podstawowy imperatyw w działaniu. Dla św. Pawła Apostoła wszystkie dobra tego świata w porównaniu z miłością nic nie znaczą ${ }^{38}$. Zwieńczeniem hymnu jest wyrażenie przekonania o tym, że miłość nigdy nie ustaje, a w wieczności takie cnoty jak wiara i nadzieja przestaną być potrzebne, bowiem na zawsze pozostanie najważniejsza miłość. Ją też stawia na pierwszym miejscu, kiedy

\footnotetext{
${ }^{36}$ Por. W. Giertych, Rozważania Pawłowe, Warszawa 2008, s. 51.

${ }^{37}$ Modlitwa po komunii, [w:] Mszat rzymski dla diecezji polskich, dz. cyt., s. 10'.

${ }^{38}$ Por. P. Łabuda, Dziewięć spotkań ze św. Pawłem, Tarnów 2008, s. 34.
} 
wymienia różne owoce Ducha - sprawcę komunii wspólnoty chrześcijańskiej (por. Ga 5, 22).

„Dar jedności w Duchu Świętym” (2 Kor 13, 13) ${ }^{39}$ jest skutkiem pobudzania Trzeciej Osoby Boskiej do zacieśniania więzi braterskiej miłości ze wszystkimi ludźmi. Miłując się nawzajem, chrześcijanie pozwalają Temu, który jest Panem i Ożywicielem, działać i wyrażać się w całej pełni. Rozumiejąc tę tajemnicę wiary, Apostoł Narodów we fragmencie jednego z swoich listów o stosunku do współbraci zestawia dwa wezwania: „Bądźcie płomiennego ducha”, „Nikomu złem za zło nie odpłacajcie” (Rz 12, 11. 17) ${ }^{40}$.

Wzorem miłości jest Bóg i On poucza swój lud o dojrzałej miłość bliźniego, która wyraża się brakiem lęku, dążeniem do doskonałości, życiem prawdą i poznaniem Bożych tajemnic. W biblijnych tekstach autora Hymnu o miłości istota takiej postawy i sposób jej urzeczywistniania przestają być pojęciami abstrakcyjnymi i przybierają konkretny oraz praktyczny charakter. Wszystkie charyzmaty - jak wynika z 1 Kor 13,1-13 - mają wyjątkową wartość, a ich rola o tyle jest cenniejsza, o ile bardziej wykorzystywane są w służbie bliźnim ${ }^{41}$.

Pragnienie dostrzeżenia u Apostoła Narodów konkretnej drogi do poznania wiary i prawdy, z których wywodzą się motywy jedności uczniów Chrystusa, stało u źródeł decyzji ogłoszenia przez Benedykta XVI Roku św. Pawła. Z życia Świętego z Tarsu papież pragnie wydobyć tę postawę i ukazać ją chrześcijanom XXI wieku: „Prawda, której doświadczył, spotykając Zmartwychwstałego, była dla niego warta walki, znoszenia prześladowań i cierpienia. Ale najgłębszym motywem była miłość, jaką darzył go Jezus Chrystus, a także pragnienie przekazania tej miłości innym. Paweł był człowiekiem zdolnym do miłości i tylko wychodząc od tego, można pojąć cała jego działalność oraz cierpienia" ${ }^{42}$.

Wierni, którzy zgromadzą się na modlitwie w dniach poświęconych św. Pawłowi, mogą ożywiać i wyrażać wdzięczność Bogu za tak niezwykłą postać z czasów kształtowania się Kościoła. Dzięki liturgicznym tekstom ukazującym życie i dzieło Apostoła spoglądają na wybranego do głoszenia Dobrej Nowiny byłego prześladowcę chrześcijan i poznają, jak zmienił się

${ }^{39}$ Por. Obrzędy wstępne, [w:] Mszat rzymski dla diecezji polskich, dz. cyt., s. 3*. Prawda o jednoczącym działaniu Trzeciej Osoby Boskiej z 2 Kor 13, 13 stanowi pozdrowienie wiernych zgromadzonych na celebrację mszy świętej: „Miłość Boga Ojca, łaska naszego Pana Jezusa Chrystusa i dar jedności w Duchu Świętym niech będą z wami wszystkimi”.

${ }^{40}$ Por. Benedykt XVI, Pawet - Duch Święty w naszych sercach, dz. cyt., s. 33.

${ }^{41}$ Por. A. Paciorek. Pawet Apostot - pisma, cz. 1, Tarnów 2000, s. 114; por. E. Szymanek. Wykład Pisma Świętego Nowego Testamentu, dz. cyt., s. 311.

${ }^{42}$ Benedykt XVI, Stuchajmy św. Pawła i uczmy się od niego. Homilia podczas Nieszporów w bazylice św. Pawta za Murami (28 czerwca 2008), [w:] Modlitwy na Rok świętego..., dz. cyt., s. 5. 
on, miłując Chrystusa i Jego Mistyczne Ciało. W ten sposób lud Boży pomnaża w sobie pragnienie rozwoju przyjaźni ze Zbawicielem i miłości do bliźnich, potęguje dobro, którego doświadcza się przez nawrócenie. Stąd zrozumiałym wydaje się papieskie nauczanie dotyczące zażyłych relacji wiernych ze Zbawicielem: „Jeżeli etyka, jaką Paweł proponuje wierzącym, nie popada w formy moralizmu i okazuje się aktualna dla nas, to dlatego, że za każdym razem wychodzi zawsze od osobistego i wspólnotowego związku z Chrystusem, by ukonkretnić się w życiu zgodnie z Duchem. To jest zasadnicze: etyka chrześcijańska nie rodzi się z systemu przykazań, lecz jest następstwem naszej przyjaźni z Chrystusem. Przyjaźń ta wpływa na życie: jeśli jest prawdziwa, wciela się i spełnia w miłości do bliźniego. Dlatego jakikolwiek upadek etyczny nie ogranicza się do sfery indywidualnej, lecz jest zarazem dewaluacją wiary osobistej i wspólnotowej: z niej wypływa i na nią oddziałuje w sposób determinujący. Pozwólmy się zatem dosięgnąć pojednaniu, którym Bóg nas obdarzył w Chrystusie, «szalonej» miłości Boga do nas: nic i nikt nie zdoła nas nigdy odłączyć od Jego miłości (por. Rz 8, 39). Tą pewnością żyjemy. I to ta pewność daje nam siły do konkretnego życia wiarą, która działa w miłości”43.

Ukazane w liturgii Kościoła życie i działanie św. Pawła przekonują, że autentyczne spotkanie z Jezusem jest zawsze dla człowieka przemieniające. Apostoł, napełniony Duchem Świętym, poznał tajemnice Bożego zbawienia, które pozwoliły mu przyjąć powołanie do głoszenia Ewangelii, z chrześcijańską miłością być zatroskanym o wszystkich ludzi oraz przez ofiarę swojego życia kroczyć drogą przyjaźni z Chrystusem. Ogłaszając Rok św. Pawła, Benedykt XVI pragnął, aby chrześcijanie XXI wieku na przykładzie Apostoła Narodów na nowo zrozumieli Ewangelię i ożywili swoje zaangażowanie w głoszenie jej wszystkim i wszędzie. Każdy człowiek powołany bowiem został do niekończącej się bliskości z Chrystusem, który (podobnie jak pod Damaszkiem) pragnie objawiać się wszystkim ludziom i przemieniać ich życie w służbę naznaczoną miłością.

Czerpiąc z bogactwa liturgii Kościoła o św. Pawle, z którego wciąż promieniuje jasne słońce prowadzące do Chrystusa, chrześcijanin może kształtować swoje życie duchowe. Kościół - na przykładzie Apostoła wskazuje na proste i trwałe elementy tożsamości chrześcijańskiej, od których zależy zjednoczenie człowieka z jego Stwórcą. Odpowiadają one na pytania o sens i cel ludzkiego życia, jakimi są oddawanie należnej Bogu chwały i osiągnięcie zbawienia.

\footnotetext{
${ }^{43}$ Benedykt XVI, Katecheza podczas audiencji ogólnej 26 listopada 2008.
} 


\section{Słowa kluczowe}

Św. Paweł Apostoł, msza święta, liturgia godzin, życie duchowe

\section{Summary}

The life and activity of St. Paul the Apostle according to the Liturgy of the Church

In the liturgical calendar St. Paul is mentioned twice - for the first time on the day of his conversion (25 January), and then during the celebration - in common with St. Peter the Apostle - when the congregation contemplates his life and martyr's death (29 June). In this article, through the analysis of liturgical texts about St. Paul - biblical readings and forms of the Holy Mass, and Liturgy of the Hours - the spiritual richness and depth of mysteries of salvation are transmitted to the Church community by this Apostle of the Nations.

The Apostle of Tarsus, through his life and deeds showed us the power of the Holy Spirit operating in mankind, who makes us God's children and lets us live not according to worldly but according to spiritual values. By giving His gifts to people, He contributes to the development of the Church. The Apostle is also the example of acceptance of the Gospel, which is revealed through preaching the Good News to all peoples. He shows that one can endure pain and suffering for sake of the Gospel. And sacrificing our life, giving it for the act of salvation leads to friendship with Christ and brotherly love. The liturgical texts which are designed to be prayed on St. Paul's days deeper the certainty that God's people have that Jesus was resurrected and is alive, and wishes to lead each man on the way to salvation.

\section{Keywords}

St. Paul Apostle, Holy Mass, Liturgy of the Hours, spiritual life 